\title{
EFEKTIVITAS MODIFIKASI BUBU DASAR KONSTRUKSI ATRAKTOR TERHADAP HASIL TANGKAPAN IKAN DI PERAIRAN PULAU LEMUKUTAN
}

\section{EFFECTIVENESS OF MODIFICATION BOTTOM TRAPS CONSTRUCTION ATTRACTORS ABOUT CATCHES FISH IN LEMUKUTAN ISLAND WATERS}

\author{
Ho Putra Setiawan ${ }^{1}$, Sadri $^{1}$, Agus Setiawan ${ }^{2}$, Slamet Tarno ${ }^{2}$ \\ ${ }^{1}$ Program Studi Teknologi Penangkapan Ikan, \\ ${ }^{2}$ Program Studi Teknologi Budidaya Ikan, \\ Jurusan Ilmu Kelautan dan Perikanan, Politeknik Negeri Pontianak \\ Korespondensi : hoputra_setiawan915615@yahoo.co.id
}

\begin{abstract}
Trap have different construction to catch the fishes. The purpose of this study is to obtain the basic trap construction model, analyze the effectiveness of basic construction modifications, and financial analysis. The acquisition of catch composition shows that red snapper (Lutjanus alfifrotouris) gets the largest proportion in unit weight (kg) at a depth of $10 \mathrm{~m}$ for modification of basic trap attractors construction beam model of $27,49 \%$ and construction does not use attractors at $16,45 \%$, and at the depth of $14 \mathrm{~m}$ for modification of the base trap attractor construction beam model is $27,40 \%$ and the construction does not use attractors at $24,97 \%$, while the largest proportion in units of number (tail) at a depth of $10 \mathrm{~m}$ yellow tail fish (Caesio erythrogaster) is 37,89\% while construction beam models do not use attractors at $22,80 \%$ and at $14 \mathrm{~m}$ depth the largest proportion obtained in units of number (tail) is found in yellow tail fish (Caesio erythrogaster) for modification of the base trap attractor construction beam model of $25,64 \%$ while the construction does not use contractor at 19,94\%. The diversity index value $\left(H^{\prime}\right)$ of Lemukutan Island waters region is 3,9 while the comparative analysis of fish production (one-way anova) shows that the treatment of the two fishing gear construction models did not significantly affect the production of fish caught at a depth of $10 \mathrm{~m}$ and $14 \mathrm{~m}$. The results of the R/C ratio showed that the modified fishing gear of the attractor construction beam model obtained an $\mathrm{R} / \mathrm{C}=1,435$ and the construction did not use the attractor $\mathrm{R} / \mathrm{C}$ value $=1,031$, thus the two basic construction models were economically feasible to develop as a business arrest in Lemukutan Island waters.
\end{abstract}

Keyword: attractors, bottom traps, concrete cor, modification

\begin{abstract}
ABSTRAK
Bubu memiliki konstruksi yang berbeda untuk menangkap ikan. Tujuan penelitian ini adalah mendapatkan model konstruksi bubu dasar, menganalisa efektivitas modifikasi konstruksi bubu dasar, dan analisis finansial. Perolehan komposisi hasil tangkapan menunjukkan ikan kakap merah (Lutjanus alfifrotouris) mendapat proporsi terbesar dalam satuan berat $(\mathrm{kg})$ pada kedalaman 10 m untuk modifikasi bubu dasar model balok konstruksi atraktor sebesar 27,49\% dan konstruksi tidak menggunakan atraktor sebesar 16,45\%, dan pada kedalaman $14 \mathrm{~m}$ untuk modifikasi bubu dasar model balok konstruksi atraktor sebesar $27,40 \%$ dan konstruksi tidak menggunakan atraktor sebesar 24,97\%, sedangkan proporsi terbesar dalam satuan jumlah (ekor) pada kedalaman $10 \mathrm{~m}$ untuk modifikasi bubu dasar model balok konstruksi atraktor terdapat pada ikan ekor kuning (Caesio erythrogaster) sebesar 37,89\% sedangkan model balok konstruksi tidak menggunakan atraktor adalah sebesar 22,80\% dan pada kedalaman $14 \mathrm{~m}$ proporsi terbesar yang diperoleh dalam satuan jumlah (ekor) terdapat pada ikan ekor kuning (Caesio erythrogaster) untuk modifikasi bubu dasar model balok konstruksi atraktor sebesar 25,64\% sedangkan konstruksi tidak menggunakan atraktor sebesar 19,94\%. Nilai indeks keanekaragaman $\left(\mathrm{H}^{\prime}\right)$ wilayah perairan Pulau Lemukutan yaitu sebesar 3,9 sedangkan analisis perbandingan produksi ikan (one-way anova) menunjukkan perlakuan kedua model konstruksi alat tangkap tidak berpengaruh nyata terhadap produksi ikan yang tertangkap pada kedalaman $10 \mathrm{~m}$ dan $14 \mathrm{~m}$. Hasil analisis $R / C$ ratio menunjukkan alat tangkap bubu modifikasi model balok konstruksi atraktor memperoleh nilai $R / C=1,435$ dan konstruksi tidak menggunakan atraktor nilai $R / C$ sebesar $=1,031$, dengan demikian kedua model konstruksi bubu dasar secara ekonomis layak untuk dikembangkan sebagai usaha penangkapan di perairan Pulau Lemukutan.
\end{abstract}

Kata kunci: atraktor, bubu dasar, cor beton, konstruksi 


\section{PENDAHULUAN}

Provinsi Kalimantan Barat terletak di bagian Barat Pulau Kalimantan atau diantara garis $2^{\circ} 08 \mathrm{LU}$ dan $3^{\circ} 05 \mathrm{LS}$ serta diantara $108^{\circ} 0^{-}$BT dan $114^{\circ} 10^{\prime}$ BT. Pemanfaatan sumberdaya perikanan khususnya perikanan tangkap hingga saat ini masih didominasi oleh usaha perikanan rakyat yang umumnya memiliki karakteristik skala usaha kecil, aplikasi teknologi yang sederhana, jangkauan operasi penangkapan yang terbatas di sekitar pantai dan produktivitas yang relatif masih rendah. Menurut Barus et al. (1991), produktivitas nelayan yang rendah umumnya disebabkan oleh rendahnya keterampilan dan pengetahuan serta penggunaan alat penangkapan maupun perahu yang masih sederhana sehingga efektivitas dan efisiensi alat tangkap dan penggunaan faktorfaktor produksi lainnya belum optimal, keadaan ini sangat berpengaruh terhadap pendapatan yang diterima oleh nelayan dan akhirnya berpengaruh juga pada tingkat kesejahteraan.

$$
\text { Nugroho (1987) mengatakan }
$$

bahwa upaya penangkapan ikan adalah suatu usaha yang menghasilkan atau memanfaatkan seluruh benda-benda hidup di suatu perairan. Menurut Cekik (2003) mengatakan bahwa bubu merupakan alat tangkap pasif tradisional yang berupa perangkap ikan yang terbuat dari bambu, rotan, kawat, besi, jaring, kayu, dan plastik yang dirangkai sedemikian rupa sehingga ikan yang masuk tidak dapat keluar dimana pengoperasian bubu dilakukan dengan cara meletakan bubu di sela-sela karang atau tempat hunian ikan.

Iskandar (2011) mengemukakan bahwa bubu merupakan alat tangkap tradisional yang memiliki banyak keistimewaan antara lain: pembuatan bubu mudah dan murah, mudah dalam pengoperasian, hasil tangkapan diperoleh dalam keadaan segar, tidak merusak lingkungan ekologi perairan setempat serta ikan yang tertangkap memiliki nilai ekonomis yang cukup tinggi. Selanjutnya Bury (2011) mengatakan bahwa bubu adalah alat perangkap yang mempunyai satu atau dua pintu masuk dan dapat diangkat ke beberapa daerah penangkapan dengan mudah dengan atau tanpa perahu dan sangat efektif untuk menangkap organisme yang bergerak lambat di dasar perairan baik laut maupun danau. Lestari (2007) menambahkan bahwa bubu adalah alat perangkap yang memudahkan ikan untuk memasukinya dan menyulitkan ikan untuk keluar, alat ini sering diberi nama fishing pots atau fishing basket.

Hasil penelitian tahun pertama yang telah dilakukan oleh Setiawan et al. (2017) dengan menggunakan modifikasi konstruksi bubu dasar model balok dan modifikasi konstruksi bubu dasar model kubus serta bubu tradisional, berdasarkan analisis komposisi hasil tangkapan memperoleh hasil tangkapan sebesar $84,88 \mathrm{~kg}$ atau sebesar 690 ekor pada kedalaman $9 \mathrm{~m}$ dan $95,53 \mathrm{~kg}$ atau 800 ekor pada kedalaman $12 \mathrm{~m}$, selain itu bubu dasar model balok memiliki hasil tangkapan lebih banyak dalam satuan berat $(\mathrm{kg})$ pada kedalaman $12 \mathrm{~m}$ selanjutnya hasil analisis $R / C$ ratio menunjukkan bahwa modifikasi konstruksi bubu model balok memperoleh nilai $R / C$ ratio sebesar 1,035 dimana secara ekonomis layak digunakan dan layak dikembangkan sebagai usaha penangkapan ikan dasar di perairan Pulau Lemukutan.

Hasil penelitian yang dilakukan oleh Musbir et al. (2014) di Kabupaten Bulukumba Sulawesi Selatan memperlihatkan bahwa dengan adanya penggunaan atraktor memperoleh hasil yang lebih maksimal terhadap pemanenan anakan udang lobster, selanjutnya hasil penelitian yang telah dilakukan oleh Sutiyono et al. (2016) memperlihatkan bahwa penggunaan atraktor dari tutupan daun kelapa dan lamanya perendaman bubu dasar terhadap hasil tangkapan ikan menghasilkan hasil yang optimal pada satuan berat (kg) maupun dalam satuan jumlah (ekor) dan dalam satuan jenis (spesies). Modifikasi konstruksi model balok perlu dikembangkan dan perlu ditingkatkan upaya penangkapan sebagai alat penangkapan terpilih dimana konstruksi bubu dasar model balok tersebut perlu dimodifikasi konstruksinya dengan menggunakan atraktor dimana fungsi dari atraktor tersebut adalah untuk mengiring ikan-ikan target tangkapan agar dapat masuk ke mulut/pintu masuk bubu sehingga hasil tangkapan yang diperoleh dapat maksimal dan kesejahteraan nelayan dapat lebih baik.

Pemanfaatan potensi penangkapan ikan yang dilakukan oleh para nelayan di perairan Pulau Lemukutan dengan menggunakan atraktor sampai saat ini belum ada serta pengenalan konstruksi atraktor pada masyarakat nelayan di perairan Pulau Lemukutan masih belum diketahui sama sekali. Berdasarkan 
uraian tersebut maka perlu dilakukan penelitian mengenai "Efektivitas Modifikasi Bubu Dasar Konstruksi Atraktor terhadap Hasil Tangkapan Ikan di Perairan Pulau Lemukutan".

\section{METODE PENELITIAN}

Modifikasi konstruksi alat tangkap bubu dasar yang dilakukan dalam penelitian ini terdiri dari dua tipe model konstruksi yaitu modifikasi bubu dasar model balok konstruksi atraktor dan modifikasi bubu dasar model balok konstruksi tidak menggunakan atraktor. Modifikasi bubu dasar model balok konstruksi atraktor dan konstruksi tidak menggunakan atraktor terdiri dari 2 jenis ukuran pipa paralon yaitu berukuran $1 \frac{1 / 4}{4}$ inci dan $3 / 4$ inci. Pipa paralon berukuran $1 \frac{1 / 4}{4}$ inci merupakan kerangka dasar dari bubu yang pada keseluruhan rongga bagian dalam pipa tersebut dicor semen beton sedangkan pipa paralon ukuran 3/4 inci digunakan untuk pembuatan mulut atau pintu masuk bubu dan tidak dicor semen. Penyambung pipa berbentuk T, L, dan bentuk datar. Modifikasi konstruksi dari badan bubu dasar dalam penelitian ini adalah dengan menggunakan jaring Polyethylene $(P E)$ ukuran mata jaring $2 \frac{1}{2}$ inci. Konstruksi pintu masuk/mulut dari bubu dasar ini adalah berbentuk kotak pada bagian luar/depan maupun pada bagian dalam. Ukuran pada bagian luar/depan adalah $25 \mathrm{~cm}$ dan pada bagian dalam berukuran $15 \mathrm{~cm}$. Pintu masuk pada rancangan modifikasi konstruksi bubu dasar dalam penelitian ini terdapat enam buah pintu masuk. Pada penelitian ini kedua bubu model balok modifikasi konstruksi atraktor dan tidak menggunakan atraktor diletakkan secara bersamaan dalam satu lokasi daerah penangkapan dengan kontur dasar perairan berkarang dan berpasir pada kedalaman $10 \mathrm{~m}$ dan $14 \mathrm{~m}$.

Modifikasi bubu dasar konstruksi atraktor dan konstruksi tidak menggunakan atraktor dalam penelitian ini masing-masing berjumlah 4 unit. Teknik pengoperasian dari kedua model modifikasi konstruksi bubu dasar tersebut diletakan perkelompok dimana satu kelompok terdiri dari dua unit bubu (bubu balok modifikasi konstruksi atraktor 1 unit dan bubu balok modifikasi konstruksi tidak menggunakan atraktor 1 unit) yang di ikat saling berdekatan dengan jarak dari bubu yang satu ke bubu yang lain adalah $5 \mathrm{~m}$. Pada penelitian ini terdiri dari 4 kelompok yang mana jarak masing-masing kelompok yang satu ke kelompok yang lain adalah $10 \mathrm{~m}$ serta lama perendaman adalah 4-5 hari/96-120 jam.

\section{Analisis data}

\section{Analisis komposisi hasil tangkapan}

Komposisi hasil tangkapan diperoleh dari jumlah hasil tangkapan pada setiap alat tangkap yang digunakan (bubu balok modifikasi konstruksi atraktor dan bubu balok modifikasi konstruksi tidak menggunakan atraktor). Komposisi hasil tangkapan meliputi: jumlah jenis (ekor), bobot (gr), ukuran panjang $(\mathrm{cm})$, untuk masing-masing jenis ikan pada kedua jenis konstruksi alat tangkap yang digunakan. Perhitungan untuk produksi ikan selama pengambilan data dilakukan dengan rumus Dollu (2013):

$$
p i=\frac{n i}{N} \times 100 \%
$$

dimana :

$\rho i=$ Kelimpahan relatif hasil tangkapan (\%), $n i=$ Jumlah hasil tangkapan spesies (ekor), $N=$ Jumlah hasil tangkapan bubu (ekor)

\section{Analisis frekuensi kemunculan ikan}

Frekuensi kemunculan ikan hasil tangkapan dihitung menggunakan rumus:

$$
F i=a i / a T o t \times 100 \%
$$

dimana :

$F i=$ Frekuensi kemunculan spesies ke- $i$ $(\%)$,

$a i=$ Jumlah kemunculan setiap jenis ke- $i$ selama trip penangkapan pengambilan data,

aTot $=$ Jumlah keseluruhan trip penangkapan selama pengambilan data

Analisis keanekaragaman jenis

Perhitungan indeks keanekaragaman jenis menggunakan rumus indeks keanekaragaman Odum (1971):

$$
H^{\prime}=\sum_{n-1}^{\infty}\left(\frac{n i}{N} \log \frac{n i}{N}\right)
$$

dimana :

$H^{\prime}=$ Indeks Shannon-wianer, 
$n i=$ Jumlah individu untuk spesies ke- $i$,

$N$ = Jumlah total individu dalam sampel,

Kriteria $H^{\prime}$ :

$H \leq 2 \quad=$ keanekaragaman kecil,

$2<H^{\prime} \leq 3=$ keanekaragaman sedang, dan

$H^{\prime}>3=$ keanekaragaman besar

\section{Analisis perbandingan hasil tangkapan}

Analisis perbandingan dilakukan berdasarkan produksi ikan dari ke dua bubu pada dua kedalaman (kedalaman 10 $\mathrm{m}$ dan $14 \mathrm{~m}$ ). Perbandingan produksi ikan antara ke dua bentuk konstruksi bubu pada masing-masing kedalaman dilakukan dengan menggunakan uji statistik one-way anova. Hipotesis untuk uji ini adalah $\mathrm{H}_{\mathrm{O}}=$ Bentuk konstruksi bubu yang dibandingkan memiliki rata-rata yang sama, $\mathrm{H}_{1}=$ Bentuk konstruksi bubu yang dibandingkan tidak memiliki rata-rata yang sama. Kaidah pengambilan keputusan: jika nilai signifikan $>0,05$, maka $\mathrm{H}_{\mathrm{O}}$ diterima, jika nila signifikan $<0,05$ maka $\mathrm{H}_{\mathrm{O}}$ ditolak.

\section{Analisis perbandingan produksi kedalaman}

Analisis uji perbandingan produksi ikan antara kedalaman pada kedua konstruksi bubu dilakukan dengan uji $\mathrm{T}$. Hipotesis untuk uji ini adalah $\mathrm{H}_{\mathrm{O}}=$ Tidak ada perbedaaan rata-rata antara kondisi sebelum dan sesudah, $\mathrm{H}_{1}=$ Terdapat perbedaan ratarata antara kondisi sebelum dan sesudah. Kaidah pengambilan keputusan: jika nilai signifikan > 0,05, maka $\mathrm{H}_{\mathrm{O}}$ diterima, jika nilai signifikan $<0,05$, maka $\mathrm{H}_{\mathrm{O}}$ ditolak.

\section{Analisis finansial modifikasi bubu dasar}

Analisis finansial modifikasi konstruksi bubu dilakukan melalui analisis imbangan penerimaan dan biaya (revenuecost ratio). Analisis revenue-cost ratio dilakukan untuk mengetahui seberapa jauh setiap nilai rupiah biaya yang digunakan dalam kegiatan usaha dapat memberikan sejumlah nilai penerimaan sebagai manfaatnya. Kegiatan usaha yang paling menguntungkan mempunyai $R / C$ paling besar. Perhitungan $R / C$ menggunakan persamaan antara lain:

$R / C=$ Total penerimaan/biaya, dengan kriteria: Jika $R / C>1$, kegiatan usaha mendapat keuntungan, Jika $R / C<1$, kegiatan usaha menderita kerugian, dan Jika $R / C=1$, kegiatan usaha tidak memperoleh keuntungan atau kerugian.

\section{HASIL DAN PEMBAHASAN}

\section{Posisi lokasi penelitian}

Peta lokasi pengambilan data penelitian di perairan Pulau Lemukutan seperti terlihat pada Gambar 1 di bawah ini terhadap kedua model konstruksi bubu dasar terletak pada empat titik posisi koordinat antara lain: Kelompok 1 terletak pada posisi koordinat $0^{\circ} 43^{\prime} 14^{\prime \prime} \mathrm{LU}-108^{\circ} 44^{\prime} 18^{\prime \prime} \mathrm{BT}$, Kelompok 2 terletak pada posisi koordinat $0^{\circ} 43^{\prime} 12^{\prime \prime} \mathrm{LU}$ - 108 44'05" BT, Kelompok 3 terletak pada posisi koordinat $0^{\circ} 43^{\prime} 36^{\prime \prime} \mathrm{LU}$ $108^{\circ} 44^{\prime} 40^{\prime \prime}$ BT dan Kelompok 4 terletak pada posisi koordinat $0^{\circ} 43^{\prime} 52^{\prime \prime} \mathrm{LU}-108^{\circ} 44^{\prime} 45^{\prime \prime}$ BT.

Pelaksanaan pengambilan data penelitian dilakukan selama 22 kali setting dan hauling yang terdiri dari 11 trip yaitu pada tanggal 7 Juli, 13 Juli, 18 Juli, 24 Juli, 29 Juli, 3 Agustus, 8 Agustus, 14 Agustus, 21 Agustus, 26 Agustus, dan 31 Agustus 2018.

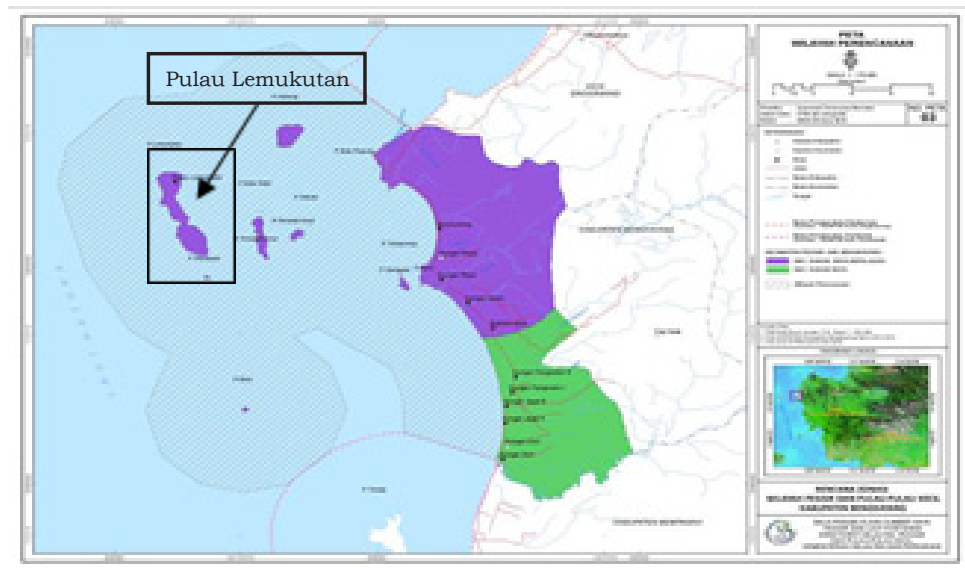

Gambar 1. Peta lokasi penelitian 


\section{Produksi hasil tangkapan ikan}

Total produksi hasil tangkapan ikan pada modifikasi bubu dasar model balok konstruksi atraktor dan modifikasi bubu dasar model balok konstruksi tidak menggunakan atraktor pada kedalaman 10 $\mathrm{m}$ dan $14 \mathrm{~m}$ selama 11 trip penangkapan dapat dilihat pada Tabel 1 .

Berdasarkan Tabel 1, hasil produksi terbanyak pada kedalaman $10 \mathrm{~m}$ terdapat pada alat tangkap bubu dasar model balok konstruksi atraktor yaitu sebanyak 4 jenis kemudian diikuti oleh alat tangkap bubu dasar model balok konstruksi tidak menggunakan atraktor yaitu sebanyak 3 jenis sedangkan hasil produksi terbanyak pada kedalaman $14 \mathrm{~m}$ terdapat pada bubu dasar model balok konstruksi atraktor yaitu sebanyak 4 jenis kemudian diikuti oleh bubu dasar model balok konstruksi tidak menggunakan atraktor sebanyak 4 jenis.

Jenis ikan hasil tangkapan pada Tabel 2 terdiri dari ikan-ikan dasar spesies Caesio erythrogaster, Siganus sp, Lutjanus alfifrotouris, dan Epinephelustouvina sp.

\section{Komposisi hasil tangkapan ikan}

Hasil tangkapan ikan dalam penelitian ini terdiri dari 4 jenis dengan memiliki komposisi yang berbeda pada masing-masing konstruksi alat tangkap dan pada kedalaman yang berbeda. Komposisi hasil tangkapan diperoleh dari: jumlah hasil tangkapan pada setiap jenis alat tangkap yang digunakan (modifikasi bubu dasar model balok konstruksi atraktor dan modifikasi bubu dasar model balok konstruksi tidak menggunakan atraktor.

Gambar 2 menunjukkan bahwa komposisi hasil tangkapan ikan pada modifikasi bubu dasar model balok konstruksi atraktor yang digunakan dalam satuan berat $(\mathrm{kg})$ untuk kedalaman $10 \mathrm{~m}$ yang paling dominan tertangkap adalah ikan kakap merah (Lutjanus alfifrotouris) yaitu sebesar 27,49\%, selanjutnya komposisi hasil tangkapan terkecil dari 4 jenis ikan yang tertangkap yaitu terdapat pada ikan baronang (Siganus sp) sebanyak 6,8\%. Total komposisi hasil tangkapan pada modifikasi bubu dasar model balok konstruksi atraktor yang digunakan dalam satuan berat $(\mathrm{kg})$ pada kedalaman $10 \mathrm{~m}$ adalah $372,61 \mathrm{~kg}$.

Gambar 3 menunjukkan bahwa komposisi hasil tangkapan ikan pada modifikasi bubu dasar model balok konstruksi tidak menggunakan atraktor dalam satuan berat $(\mathrm{kg})$ untuk kedalaman 10 $\mathrm{m}$, yang paling dominan tertangkap adalah ikan kakap merah (Lutjanus alfifrotouris) yaitu sebesar 16,45\%, selanjutnya komposisi hasil tangkapan terkecil dari 3 jenis ikan yang tertangkap terdapat pada ikan baronang (Siganus sp) yaitu sebanyak 1,34\%. Total komposisi hasil tangkapan pada modifikasi bubu dasar model balok konstruksi tidak menggunakan atraktor yang digunakan dalam satuan berat $(\mathrm{kg})$ pada kedalaman $10 \mathrm{~m}$ adalah $181,07 \mathrm{~kg}$.

Gambar 4 menunjukkan bahwa komposisi hasil tangkapan ikan pada modifikasi bubu dasar model balok konstruksi atraktor dalam satuan jumlah (ekor) untuk kedalaman $10 \mathrm{~m}$ yang paling dominan tertangkap adalah ikan ekor kuning (Caesio erythrogaster) yaitu sebesar $37,89 \%$, selanjutnya komposisi hasil tangkapan terkecil dari 4 jenis ikan yang tertangkap terdapat pada ikan baronang (Siganus sp) yaitu sebanyak 9,3\%. Total komposisi hasil tangkapan pada modifikasi bubu dasar model balok konstruksi atraktor yang digunakan dalam satuan jumlah (ekor) pada kedalaman $10 \mathrm{~m}$ adalah 1.905 ekor.

Gambar 5 menunjukkan bahwa komposisi hasil tangkapan ikan pada modifikasi bubu dasar model balok konstruksi tidak menggunakan atraktor dalam satuan jumlah (ekor) untuk kedalaman $10 \mathrm{~m}$, yang paling dominan tertangkap adalah ikan ekor kuning (Caesio erythrogaster) yaitu sebesar 22,8\%, selanjutnya komposisi hasil tangkapan terkecil dari 3 jenis ikan yang tertangkap terdapat pada ikan kakap merah (Lutjanus alfifrotouris) yaitu sebanyak 1,14\%. Total komposisi hasil tangkapan pada modifikasi bubu dasar model balok konstruksi tidak menggunakan atraktor yang digunakan dalam satuan jumlah (ekor) pada kedalaman $10 \mathrm{~m}$ adalah 669 ekor.

Gambar 6 menunjukkan bahwa komposisi hasil tangkapan ikan pada modifikasi bubu dasar model balok konstruksi atraktor yang digunakan dalam satuan berat $(\mathrm{kg})$ untuk kedalaman $14 \mathrm{~m}$ yang paling dominan tertangkap adalah ikan kakap merah (Lutjanus alfifrotouris) yaitu sebesar 27,40\%, selanjutnya komposisi hasil tangkapan terkecil dari 4 jenis ikan yang tertangkap yaitu terdapat pada ikan baronang (Siganus sp) sebanyak 6,02\%. Total komposisi hasil tangkapan pada modifikasi bubu dasar model balok konstruksi atraktor yang digunakan dalam satuan berat $(\mathrm{kg})$ pada kedalaman $10 \mathrm{~m}$ adalah $558,3 \mathrm{~kg}$. 
Tabel 1. Jenis ikan hasil tangkapan

\begin{tabular}{clcc}
\hline \multirow{2}{*}{ No. } & \multirow{2}{*}{ Model Bubu Balok } & \multicolumn{2}{c}{ Kedalaman } \\
\cline { 3 - 4 } & & $\mathbf{1 0}$ meter & $\mathbf{1 4}$ meter \\
\hline 1. & Konstruksi atraktor & 4 Jenis & 4 Jenis \\
2. & Konstruksi tanpa atraktor & 3 Jenis & 4 Jenis \\
\hline
\end{tabular}

Tabel 2. Jenis ikan yang tertangkap pada kedua konstruksi bubu yang digunakan

\begin{tabular}{cll}
\hline No & \multicolumn{1}{c}{ Nama Indonesia } & \multicolumn{1}{c}{ Nama Ilmiah } \\
\hline 1. & Ikan Ekor Kuning & Caesio erythrogaster \\
2. & Ikan Baronang & Siganus sp \\
3. & Ikan Kakap Merah & Lutjanus alfifrotouris \\
4. & Ikan Kambing & Pomachanthusanularis sp \\
\hline
\end{tabular}

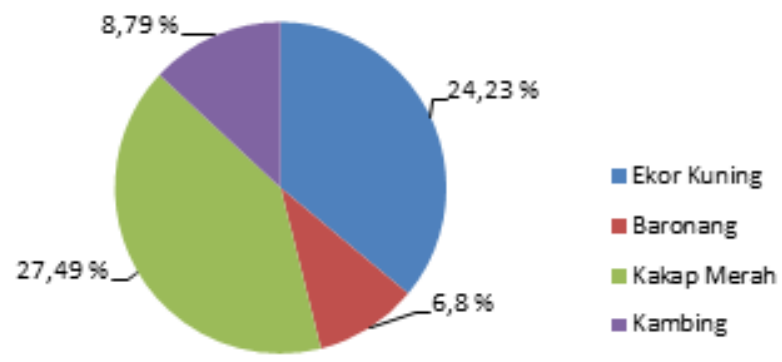

Gambar 2. Komposisi hasil tangkapan ikan (kg), konstruksi atraktor pada kedalaman $10 \mathrm{~m}$

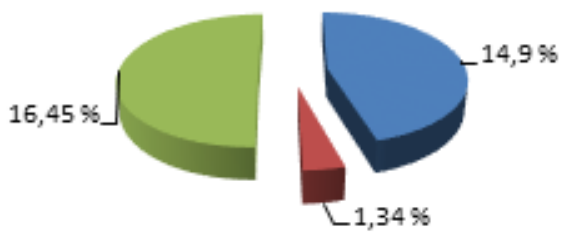

\section{Ekor Kuning}

Baronang

- Kakap Merah

Gambar 3. Komposisi hasil tangkapan ikan (kg), konstruksi tidak menggunakan atraktor pada kedalaman $10 \mathrm{~m}$ 


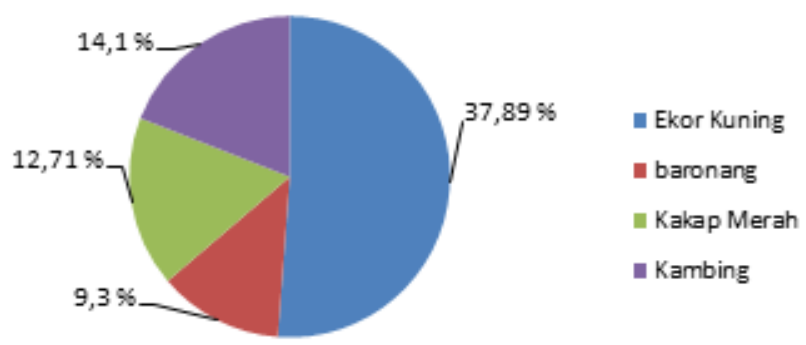

Gambar 4. Komposisi hasil tangkapan ikan (ekor), konstruksi atraktor pada kedalaman $10 \mathrm{~m}$

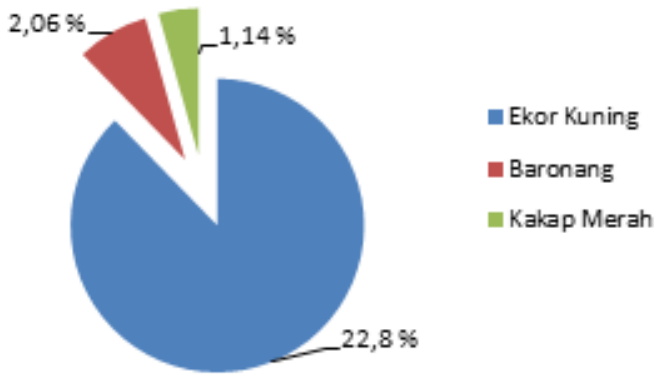

Gambar 5. Komposisi hasil tangkapan ikan (ekor), konstruksi tidak menggunakan atraktor pada kedalaman $10 \mathrm{~m}$

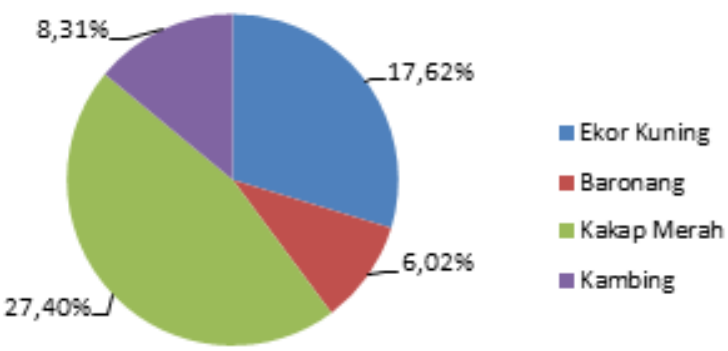

Gambar 6. Komposisi hasil tangkapan ikan (kg), konstruksi atraktor pada kedalaman $14 \mathrm{~m}$ 
Gambar 7 menunjukkan bahwa komposisi hasil tangkapan ikan pada modifikasi bubu dasar model balok konstruksi tidak menggunakan atraktor dalam satuan berat $(\mathrm{kg})$ untuk kedalaman 14 $\mathrm{m}$, yang paling dominan tertangkap adalah ikan ekor kuning (Caesio erythrogaster) yaitu sebesar $24,97 \%$, selanjutnya komposisi hasil tangkapan terkecil dari 4 jenis ikan yang tertangkap terdapat pada ikan kambing (Pomachanthusanularis $s p$ ) yaitu sebanyak $0,45 \%$. Total komposisi hasil tangkapan pada modifikasi bubu dasar model balok konstruksi tidak menggunakan atraktor yang digunakan dalam satuan berat $(\mathrm{kg})$ pada kedalaman $14 \mathrm{~m}$ adalah 382,2 kg.

Gambar 8 menunjukkan bahwa komposisi hasil tangkapan ikan pada modifikasi bubu dasar model balok konstruksi atraktor dalam satuan jumlah (ekor) untuk kedalaman $14 \mathrm{~m}$ yang paling dominan tertangkap adalah ikan ekor kuning (Caesio erythrogaster) yaitu sebesar 25,64\%, selanjutnya komposisi hasil tangkapan terkecil dari 4 jenis ikan yang tertangkap terdapat pada ikan baronang (Siganus sp) yaitu sebanyak 8,32\%. Total komposisi hasil tangkapan pada modifikasi bubu dasar model balok konstruksi atraktor yang digunakan dalam satuan jumlah (ekor) pada kedalaman $14 \mathrm{~m}$ adalah 2,484 ekor.

Gambar 9 menunjukkan bahwa komposisi hasil tangkapan ikan pada modifikasibubudasarmodelbalokkonstruksi tidak menggunakan atraktor dalam satuan jumlah (ekor) untuk kedalaman 14 m yang paling dominan tertangkap adalah ikan ekor kuning (Caesio erythrogaster) yaitu sebesar 19,94\%, selanjutnya komposisi hasil tangkapan terkecil dari 4 jenis ikan yang tertangkap terdapat pada ikan kambing (Pomachanthusanularis $s p$ ) yaitu sebanyak $1,52 \%$. Total komposisi hasil tangkapan pada modifikasi bubu dasar model balok konstruksi tidak menggunakan atraktor yang digunakan dalam satuan jumlah (ekor) pada kedalaman $14 \mathrm{~m}$ adalah 1,397 ekor.

\section{Frekuensi kemunculan ikan}

Frekuensi kemunculan ikan hasil tangkapan pada masing-masing konstruksi alat tangkap yang dioperasikan pada kedalaman yang berbeda yaitu kedalaman $10 \mathrm{~m}$ dan kedalaman $14 \mathrm{~m}$ memiliki frekuensi kemunculan yang berbeda.

Gambar 10 memperlihatkan bahwa frekuensi kemunculan ikan hasil tangkapan ke dua konstruksi bubu pada kedalaman $10 \mathrm{~m}$ paling banyak terdapat pada ikan ekor kuning (Caesio erythrogaster) yaitu sebesar $60,69 \%$ dan frekuensi kemunculan ikan hasil tangkapan paling sedikit terdapat pada ikan baronang (Siganus sp) yaitu sebesar $11,36 \%$.

Gambar 11 memperlihatkan bahwa frekuensi kemunculan ikan hasil tangkapan ke dua konstruksi bubu pada kedalaman $14 \mathrm{~m}$ paling banyak terdapat pada ikan ekor kuning (Caesio erythrogaster) yaitu sebesar $45,58 \%$ dan frekuensi kemunculan ikan hasil tangkapan paling sedikit terdapat pada ikan Baronang (Siganus $s p$ ) yaitu sebesar $10,93 \%$.

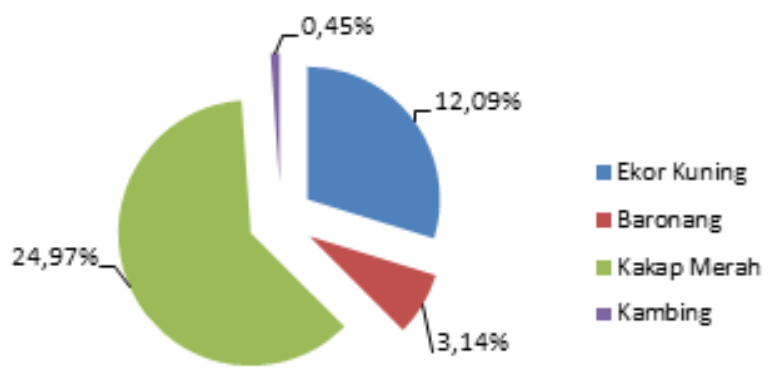

Gambar 7. Komposisi hasil tangkapan ikan (kg), konstruksi tidak menggunakan atraktor pada kedalaman $14 \mathrm{~m}$ 


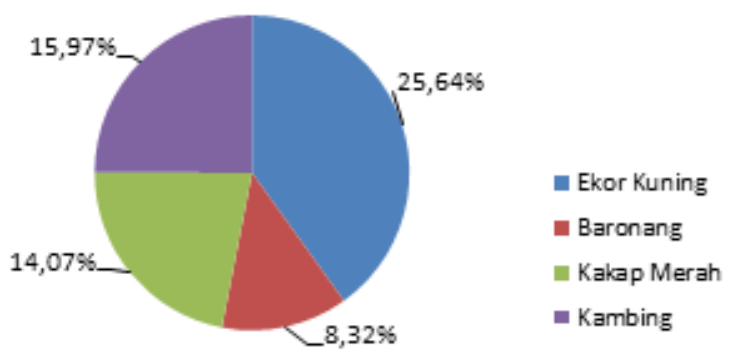

Gambar 8. Komposisi hasil tangkapan ikan (ekor), konstruksi atraktor pada kedalaman $14 \mathrm{~m}$

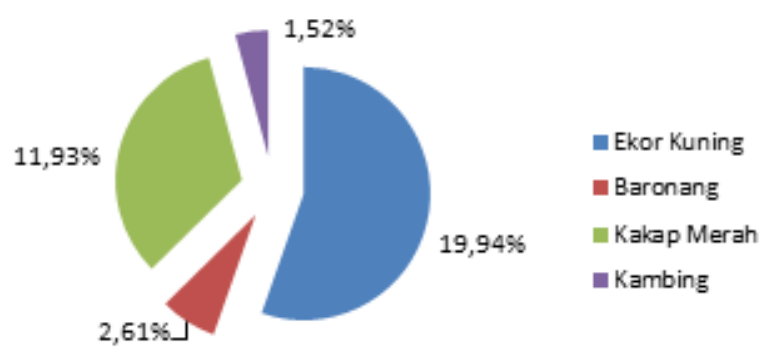

Gambar 9. Komposisi hasil tangkapan ikan (ekor), konstruksi tidak menggunakan atraktor pada kedalaman $14 \mathrm{~m}$

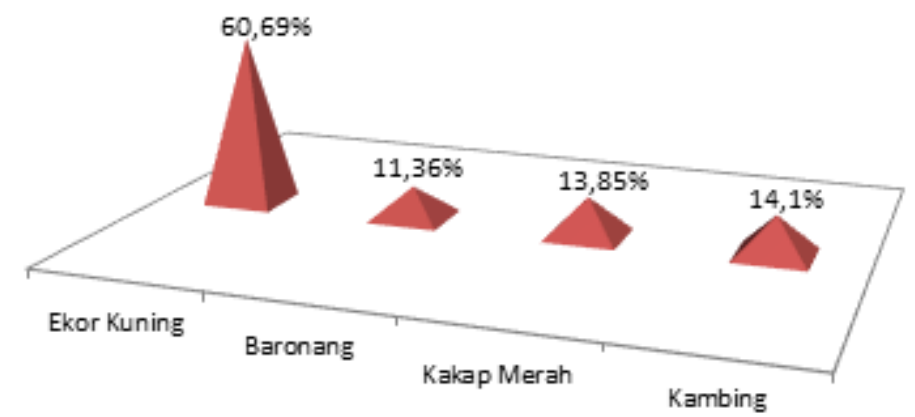

Gambar 10. Frekuensi kemunculan ikan ke dua konstruksi bubu dasar pada kedalaman $10 \mathrm{~m}$ 


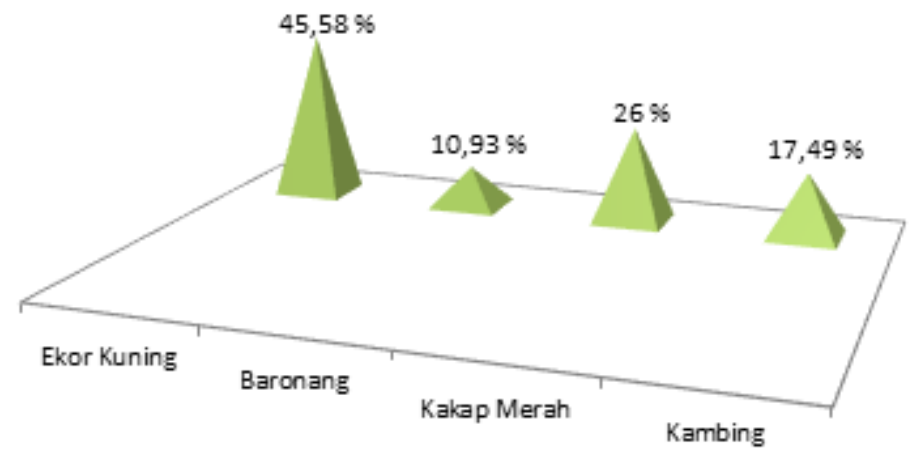

Gambar 11. Frekuensi kemunculan ikan ke dua konstruksi bubu dasar pada kedalaman $14 \mathrm{~m}$

\section{Keanekaragaman jenis ikan hasil tangkapan}

Keanekaragaman jenis ikan merupakan indeks yang digunakan untuk menduga kondisi suatu perairan berdasarkan komponen biologisnya. Kondisi suatu perairan dikatakan baik apabila memiliki keanekaragaman jenis yang tinggi. Berdasarkan hasil perhitungan dari kedua model konstruksi bubu yang digunakan dalam penelitian dan berdasarkan tingkat kedalaman perairan (kedalaman $10 \mathrm{~m}$ dan $14 \mathrm{~m})$ maka diperoleh jenis ikan dengan keanekaragaman tertinggi terdapat pada jenis ikan ekor kuning (Caesio erythrogaster). Perhitungan indeks keanekaragaman jenis untuk ke dua konstruksi bubu dapat dilihat pada Tabel 3.

\section{Analisis uji perbandingan produksi ikan}

Perbandingan produksi ikan antara ke dua model konstruksi bubu yang digunakan untuk masing-masing kedalaman yang berbeda dimana dalam penelitian ini menggunakan analisis one-way anova. Hasil perhitungan uji perbandingan produksi ikan untuk ke dua model konstruksi bubu dasar pada tingkat kedalaman $10 \mathrm{~m}$ dapat dilihat pada Tabel 4.

Pada tabel 4 diatas memperlihatkan interprestasi statistik deskriptif bubu balok tanpa atraktor pada kedalaman $10 \mathrm{~m}$ memiliki rata-rata jumlah tangkapan 223 ekor dan jumlah tangkapan maksimum sebanyak 587 ekor serta jumlah tangkapan minimum sebanyak 29 ekor sedangkan interprestasi statistik deskriptif bubu balok atraktor nilai rata-rata jumlah tangkapan sebanyak 476,25 ekor dan jumlah maksimum tangkapan 975 ekor serta jumlah minimum tangkapan sebanyak 240 ekor.

Hasil analisis ANOVA memperlihatkan bahwa pada kedalaman 10 $\mathrm{m}$ antara bubu balok yang memiliki atraktor dengan bubu balok tanpa atraktor tidak memiliki perbedaan yang signifikan dalam rata-rata jumlah hasil tangkapan ikan. Hasil Analisis ragam pada Tabel 5 menunjukkan perlakuan jenis ke dua alat tangkap bubu dasar yang dioperasikan pada kedalaman $10 \mathrm{~m}$ tidak berpengaruh nyata terhadap produksi ikan yang tertangkap $(\mathrm{p}<0,05)$.

Tabel 6 memperlihatkan interprestasi statistik deskriptif bubu balok tanpa atraktor pada kedalaman $14 \mathrm{~m}$ memiliki rata-rata jumlah tangkapan 349,25 ekor dan jumlah tangkapan maksimum sebanyak 774 ekor serta jumlah tangkapan minimum sebanyak 59 ekor sedangkan interprestasi statistik deskriptif bubu balok atraktor nilai ratarata jumlah tangkapan sebanyak 621 ekor dan jumlah maksimum tangkapan 995 ekor serta jumlah minimum tangkapan sebanyak 323 ekor.

Hasil analisis ANOVA memperlihatkan bahwa pada kedalaman 14 $\mathrm{m}$ antara bubu balok yang memiliki atraktor dengan bubu balok tanpa atraktor tidak memiliki perbedaan yang signifikan dalam rata-rata jumlah hasil tangkapan ikan. Hasil Analisis ragam pada tabel 7 menunjukkan perlakuan jenis alat tangkap bubu dasar yang dioperasikan pada kedalaman $14 \mathrm{~m}$ tidak berpengaruh nyata terhadap produksi ikan yang tertangkap $(\mathrm{p}<0,05)$.

Analisis pendapatan usaha kedua model bubu pada kedalaman $10 \mathrm{~m}$ dan $14 \mathrm{~m}$

$\begin{array}{ccc}\text { Analisis } & \text { pendapatan } & \text { usaha } \\ \text { dilakukan untuk mengetahui } & \text { secara }\end{array}$


finansial apakah usaha perikanan bubu di perairan Pulau Lemukutan dengan menggunakan modifikasi bubu model balok konstruksi atraktor maupun modifikasi bubu model balok konstruksi tanpa atraktor menguntungkan atau tidak menguntungkan sehingga layak atau tidak layak untuk dilanjutkan atau dikembangkan.

Analisis pendapatan yang dilakukan didasarkan pada perhitungan Retum Coast Ratio $(R / C)$ dengan menggunakan perbandingan besarnya total penerimaan dari penjualan hasil tangkapan ikan terhadap biaya pengeluaran per trip operasi penangkapan dan biaya pembuatan alat tangkap bubu.

Analisis R/C modifikasi bubu model balok konstruksi atraktor

Rasio penerimaan dan biaya (Revenue - Cost Ratio) yang diperoleh dari 4 unit bubu modifikasi model balok konstruksi atraktor selama 11 trip operasi penangkapan diperoleh nilai $R / C$ adalah 1,435 yang berarti kegiatan usaha untuk ke 4 unit bubu modifikasi model balok konstruksi atraktor mendapat keuntungan dan layak untuk digunakan serta dikembangkan sebagai usaha penangkapan di perairan Pulau Lemukutan

Analisis $R / C$ modifikasi bubu model balok konstruksi tidak menggunakan atraktor

Rasio penerimaan dan biaya (Revenue - Cost Ratio) yang diperoleh dari empat unit bubu modifikasi model balok konstruksi tidak menggunakan atraktor selama 11 trip operasi penangkapan diperoleh nilai $R / C$ adalah 1,031 yang berarti kegiatan usaha untuk ke 4 unit bubu modifikasi model balok konstruksi tidak menggunakan atraktor mendapat keuntungan dan layak untuk digunakan sebagai usaha penangkapan di perairan Pulau Lemukutan.

Tabel 3. Perhitungan indeks keanekaragaman jenis terhadap ke dua model konstruksi bubu pada kedalaman $10 \mathrm{~m}$ dan $14 \mathrm{~m}$

\begin{tabular}{|c|c|c|c|c|c|}
\hline \multirow{3}{*}{ No. } & \multirow{3}{*}{ Jenis Ikan } & \multicolumn{4}{|c|}{ Keanekaragaman jenis } \\
\hline & & \multicolumn{2}{|c|}{ Kedalaman 10 M } & \multicolumn{2}{|c|}{ Kedalaman 14 M } \\
\hline & & Balok Atraktor & $\begin{array}{c}\text { Balok Tanpa } \\
\text { Atraktor }\end{array}$ & $\begin{array}{c}\text { Balok } \\
\text { Atraktor }\end{array}$ & $\begin{array}{c}\text { Balok Tanpa } \\
\text { Atraktor }\end{array}$ \\
\hline 1. & Ekor Kuning & 0,360 & 0,456 & 0,297 & 0,297 \\
\hline 2. & Baronang & 0,101 & 0,041 & 0,101 & 0,077 \\
\hline 3. & Kakap Merah & 0,408 & 0,503 & 0,462 & 0,614 \\
\hline 4. & Kambing & 0,131 & - & 0,140 & 0,011 \\
\hline \multirow{2}{*}{\multicolumn{2}{|c|}{ Total }} & 1,0 & 1,0 & 1,0 & 0,9 \\
\hline & & Menunjukk & Keanekaraga & a Besar & \\
\hline
\end{tabular}

Tabel 4. Hasil uji perbandingan produksi ikan untuk ke dua model konstruksi bubu pada kedalaman $10 \mathrm{~m}$

\begin{tabular}{|c|c|c|c|c|c|c|c|c|}
\hline \multirow{2}{*}{$\begin{array}{c}\text { Jumlah tangkapan ikan } \\
\text { pada tingkat kedalaman } \\
\qquad 10 \mathrm{~m}\end{array}$} & \multirow{2}{*}{$\mathbf{N}$} & \multirow{2}{*}{ Mean } & \multirow{2}{*}{$\begin{array}{c}\text { Std. } \\
\text { Deviation }\end{array}$} & \multirow{2}{*}{$\begin{array}{l}\text { Std. } \\
\text { Error }\end{array}$} & \multicolumn{2}{|c|}{$\begin{array}{l}95 \% \text { Confidence } \\
\text { Interval for Mean }\end{array}$} & \multirow{2}{*}{ Min } & \multirow{2}{*}{ Max } \\
\hline & & & & & $\begin{array}{l}\text { Lower } \\
\text { Bound }\end{array}$ & $\begin{array}{l}\text { Upper } \\
\text { Bound }\end{array}$ & & \\
\hline BBLKTA & 3 & 223.00 & 315.462 & 182.132 & -560.65 & 1006.65 & 29 & 587 \\
\hline BBLKA & 4 & 476.25 & 336.485 & 168.243 & -59.17 & 1011.67 & 240 & 975 \\
\hline Total & 7 & 367.71 & 328.797 & 124.274 & 63.63 & 671.80 & 29 & 975 \\
\hline
\end{tabular}


Tabel 5. Analisis uji statistik ANOVA pada kedalaman $10 \mathrm{~m}$

\begin{tabular}{lccccc}
\hline \multirow{2}{*}{$\begin{array}{c}\text { Jumlah tangkapan } \\
\text { ikan }\end{array}$} & \multicolumn{5}{c}{ Output of ANOVA } \\
\cline { 2 - 6 } & Sum of Squares & df & Mean Square & F & Sig \\
\hline Between Groups & 109946.679 & 1 & 109946.679 & 1.020 & 0.359 \\
Within Groups & 538698.750 & 5 & 107739.750 & & \\
Total & 648645.429 & 6 & & & \\
\hline
\end{tabular}

Tabel 6. Hasil uji perbandingan produksi ikan untuk ke dua model konstruksi bubu pada kedalaman $14 \mathrm{~m}$

\begin{tabular}{lllcccccc}
\hline \begin{tabular}{l} 
Jumlah tangkapan ikan \\
pada tingkat kedalaman \\
\multicolumn{1}{c}{$\mathbf{1 4}$ m }
\end{tabular} & N & Mean & $\begin{array}{c}\text { Std. } \\
\text { Deviation }\end{array}$ & $\begin{array}{c}\text { Std. } \\
\text { Error }\end{array}$ & & & \multicolumn{4}{c}{$\begin{array}{c}\mathbf{9 5 \%} \text { Confidence } \\
\text { Interval for Mean }\end{array}$} & $\begin{array}{c}\text { Lower } \\
\text { Bound }\end{array}$ & $\begin{array}{c}\text { Upper } \\
\text { Bound }\end{array}$ & Min & Max \\
\hline BBLKTA & 4 & 349.25 & 336.266 & 168.133 & -185.82 & 884.32 & 59 & 774 \\
BBLKA & 4 & 621.00 & 279.467 & 139.734 & 176.31 & 1065.69 & 323 & 995 \\
Total & 8 & 485.12 & 320.987 & 113.486 & 216.77 & 753.48 & 59 & 995 \\
\hline
\end{tabular}

Tabel 7. Analisis uji statistik ANOVA pada kedalaman $14 \mathrm{~m}$

\begin{tabular}{lccccc}
\hline \multirow{2}{*}{$\begin{array}{c}\text { Jumlah tangkapan } \\
\text { ikan }\end{array}$} & \multicolumn{5}{c}{ Output of ANOVA } \\
\cline { 2 - 6 } & Sum of Squares & df & Mean Square & F & Sig \\
\hline Between Groups & 147696.125 & 1 & 147696.125 & 1.545 & 0.260 \\
Within Groups & 573530.750 & 6 & 95588.458 & & \\
Total & 721226.875 & 7 & & & \\
\hline
\end{tabular}

\section{KESIMPULAN DAN SARAN}

\section{Kesimpulan}

Modifikasi konstruksi bubu dasar model balok konstruksi atraktor efektif menangkap ikan dasar dan dapat meningkatkan hasil pendapatan nelayan di perairan Pulau Lemukutan dibandingkan dengan konstruksi bubu dasar tidak menggunakan atraktor.

\section{Saran}

Perlu memperhatikan keadaan oseanografi yang berhubungan dengan cuaca dan arus perairan setempat sehingga operasi penangkapan dapat dilaksanakan dengan baik.

Perlu dilakukan penelitian lebih lanjut tentang penggunaan umpan buatan maupun umpan hidup dalam meningkatkan hasil tangkapan bubu modifikasi.

\section{DAFTAR PUSTAKA}

Barus. 1991. Pusat Penelitian dan Pengembangan Perikanan. Prosiding Forum II Perikanan. 18-21 Juni 1991. Jakarta. Hal. 130-137.

Bury, RB. 2011. Modification of Traps to Reduce Bycatch of Freshwater Turtles. Journal of wildlife Management. 75(1): 3-5.

Cekik M, Dal T, Basusta M, and Gokce MI. 2003. Comparison of Two Different Types of Basket Trap on Fish Catches in Uskenderun Bay. Journal Turk $J$ Vet Anim Sci. 29: 743-749.

Dollu AE. 2013. Modifikasi Konstruksi Bubu Dasar yang Dioperasikan pada Perairan Warselaleng Kabupaten Alor, Provinsi Nusa Tenggara Timur [Tesis]. Makasar: Sekolah Pascasarjana Universitas Hasanuddin Makasar.

Iskandar D. 2011. Analisis Hasil Tangkapan 
Sampingan Bubu yang Dioperasikan di Perairan Karang Kepulauan Seribu. Jurnal Saintek Perikanan. 6(2): 31-37.

Lestari L. 2007. Perbandingan Hasil Tangkapan Bubu Lipat Bubu Bercelah (Escape Gap) dan Tanpa Celah (Non Escape) di Perairan Kronjo [Tesis]. Bogor: Fakultas Perikanan dan Ilmu Kelautan, Institut Pertanian Bogor.

Musbir, Sudirman, Mahfud. 2014. Penggunaan Atraktor Buatan yang Ramah Lingkungan dalam Pemanenan Anakan Udang Lobster Laut (Panulirus spp). Jurnal IPTEKS PSP. 1(2): 95-102.

Nugroho. 1987. Analisis Laju Tangkap Sumberdaya Perikanan Demersal Periode 1975-1979 dan 1984-1986 di Pantai Utara Jawa Tengah. Jurnal Penelitian Perikanan No. 40 BPPL. Jakarta.

Odum EP. 1971. Fundamental Ecology. W.B. Sounder, Co. Philadelphia 574p.

Setiawan HP, Sadri, Setiawan A, Tarno S. 2017. Efektivitas Modifikasi Konstruksi Bubu Dasar terhadap Hasil Tangkapan Ikan di Perairan Pulau Lemukutan Kalimantan Barat. Jurnal Teknologi Perikanan dan Kelautan. 8(2): 157-167.

Sutiyono, Wahyu, Kurniawan. 2016. Perbandingan Lama Perendaman Bubu Dasar Menggunakan Tutupan Daun Kelapa terhadap Hasil Tangkapan Ikan di Teluk Kelabat Desa Pusuk Bangka Barat. Jurnal Sumberdaya Perairan. 10(2): 1-5. 